\title{
EFFICIENCY OF INTERCROPPING VEGETABLES AND SPICES RELAYED WITH POINTED GOURD
}

\author{
M. R. Islam¹ ${ }^{1}$ M. A. K. Mian², S. N. Mahfuza ${ }^{3}$, J. Hossain ${ }^{4}$ and A. Hannan ${ }^{5}$ \\ ${ }^{1}$ Senior scientific officer, Agronomy Division, RARS, BARI, Ishurdi, Pabna, Bangladesh \\ ${ }^{2}$ Principle scientific officer, Regional Agricultural Research Station Ishurdi, Pabna, Bangladesh \\ ${ }^{3}$ Scientific officer, Agronomy Division, BARI, Joydebpur, Gazipur \\ ${ }^{4}$ Scientific officer, Agronomy Division, Regional Agricultural Research Station Ishurdi, Pabna, Bangladesh \\ ${ }^{5}$ Senior scientific officer, BARI, Joydebpur, Gazipur, Bangladesh
}

Key words: Intercropping, relay, vegetables, spices, pointed gourd

\begin{abstract}
An intercropping experiment was conducted at the Regional Agricultural Research Station, BARI, Ishurdi, Pabna during 2007-2008 and 2008-2009 to find out the suitable intercrop combination for increasing total productivity and returns. Seven treatments, viz. sole pointed gourd, two times lalshak + two rows turmeric in between pointed gourd lines, two times spinach + two rows turmeric in between pointed gourd lines, one time bushbean + two rows turmeric in between pointed gourd lines, two times lalshak + two rows ginger in between pointed gourd lines, two times spinach + two rows ginger in between pointed gourd lines and one time bushbean + two rows ginger in between pointed gourd lines were compared. All the intercropping combinations were higher in terms of pointed gourd equivalent yield, gross return, gross margin and benefit cost ratio (BCR) over sole crops. The highest pointed gourd equivalent yield (105.92 $\mathrm{t} \mathrm{ha}^{-1}$ ) and gross return (Tk. $2118480 \mathrm{ha}^{-1}$ ) was found from two times spinach + two rows ginger in between pointed gourd lines combination. The land equivalent ratio was observed highest (2.29) in same combination which was similar to one time bushbean + two rows ginger in between pointed gourd lines combination. One time bushbean + two rows ginger in between pointed gourd lines combination gave the highest monetary returns in respect of gross margin (Tk.1623333 ha ${ }^{-1}$ ) and BCR (4.19). The increases in total productivity in terms of pointed gourd equivalent yields were $53.72-128.62 \mathrm{t} \mathrm{ha}^{-1}$ in intercrop combination compared to base crop.
\end{abstract}

\section{Introduction}

Intercropping is a system that might be increase total production and profitability per unit area per time per inputs without affecting the production of the sole crops (Islam et al., 2013). Pointed gourd (Trichosanthes dioica) is an important vegetables crop of Bangladesh. It is cultivated round the years in about 10020 hectares of land throughout the country (BBS, 2011). Adoption of pointed gourd by cultivators poses a threat to some traditionally grown crops like turmeric, ginger and some extent leafy vegetable, bushbean etc. due to its high market value. Pointed gourd is a long duration (8-10 month) wide spaced crop with slow growth in early stages. So, there is a scope to grow the high values vegetables (red amaranth, spinach, bushbean) as intercrop at early growth stage and relayed a shade loving crop like turmeric and ginger without hampered pointed gourd production. Vegetables and spices may be grown as intercrop and relay crop with pointed gourd as they have different growth habit, growth duration and demand for growth resources. Turmeric and ginger can be cultivated in 
Islam et al.

shady places as they are shade loving crop (Haque and Hossain, 1985; Joyachandran et al., 1991).

As such the experiment was therefore, undertaken to find out the suitable intercrop combination for increasing total productivity and returns with short duration vegetables crop with pointed gourd.

\section{Materials and Methods}

The experiment was conducted at the Regional Agricultural Research Station, BARI, Ishurdi, Pabna during 2007-2008 and 2008-2009 to find out the suitable intercrop combination for increasing total productivity and return. The treatments were $T_{1}=$ Sole pointed gourd, $T_{2}=$ Two times lalshak + two rows turmeric in between pointed gourd lines, $T_{3}=$ Two times spinach + two rows turmeric in between pointed gourd lines, $\mathrm{T}_{4}=$ One time bushbean + two rows turmeric in between pointed gourd lines, $T_{5}=$ Two times lalshak + two rows ginger in between pointed gourd lines, $T_{6}=$ Two times spinach + two rows ginger in between pointed gourd lines and $T_{7}=$ One time bushbean + two rows ginger in between pointed gourd lines. The experiment was conducted in a randomized block design with three replicatons. The unit plot size was $6.0 \mathrm{~m} \times 1.25 \mathrm{~m}$. Pointed gourd spacing was maintained as $1 \mathrm{~m} \times 1 \mathrm{~m}$. Pointed gourd, lalsak (red amaranth), spinach and bushbean were planted / sown on 2 and 7 December 2007 and 2008, respectively. Lalshak and spinach were sown for second time after harvesting of first sowing. Turmeric and ginger were relayed in between two pointed gourd lines on 16 and 28 March 2008 and 2009, respectively after harvesting of vegetables (second time) and bushbean maintaining $50 \mathrm{~cm} \times 25 \mathrm{~cm}$ spacing. Pointed gourd was harvested from 1st May, 2008 to 30 October, 2008 and 5 May 2009 to 28 October 2009 respectively. Lalshak (red amaranth) and spinach were harvested on 26-28 DAS and 35-40 DAS respectively, in both sowing times. Turmeric and ginger was harvested on 7 and 10 December 2008 and 2009, respectively. The seed rate of lalshak (red amaranth), spinach, bushbean, turmeric and ginger were 2, 20, 120, $2000 \mathrm{~kg} \mathrm{ha}{ }^{-1}$, respectively. Pointed gourd var. BARI potol-1, red amaranth var. BARI lalshak1, Local var. of spinach, turmeric var. shinduri and local var. of ginger were used in the experiment. Trelly size was $6.0 \mathrm{~m} \times 1.30 \mathrm{~m}$ (12 plants / trelly). During pointed gourd planting, $4.0 \mathrm{~kg}$ cowdung and $50 \mathrm{~g}$ TSP were applied in each pit. Urea and muriate of potash were applied at the rate of $25 \mathrm{~g}$ in each pit with three equal installments at 20,60 and 90 DAE. Lalshak was fertilized @ 108-24-40-6 kg ha-1 of N-P-K-S, respectively. Half of N and full amount of other nutrients were applied as basal dose and rest $\mathrm{N}$ was applied at 20 DAS. Second sown lalshak was fertilized with $54 \mathrm{~kg} \mathrm{ha}^{-1}$ of $\mathrm{N}$ as basal and $54 \mathrm{~kg} \mathrm{ha}^{-1}$ as top dressed at 20 DAS. Spinach was fertilized with $10 \mathrm{t} \mathrm{ha}^{-1}$ of $\mathrm{CD}+92-15-38 \mathrm{~kg} \mathrm{ha}^{-1}$ of N-P-K. Half N and full amount of other nutrients were incorporated as basal. Rest $\mathrm{N}$ was top dressed at 15 DAS. Second sown spinach was fertilized with $46 \mathrm{~kg} \mathrm{ha}^{-1}$ of $\mathrm{N}$ as basal and $46 \mathrm{~kg} \mathrm{ha}^{-1}$ was top dressed at 15 DAS. Bushbean was fertilized with 120-40-60-12-3 kg ha-1 of N-P-K-S-Zn. Half $\mathrm{N}$ and full amount of other nutrient was given as basal and rest $\mathrm{N}$ was top dressed at 30 DAS. For ginger, 160-60-160-20-4 kg ha-1 of N-P-K-S-Zn and for turmeric, 160-48-140-20-4 kg $\mathrm{ha}^{-1}$ of N-P-K-S-Zn was applied. Half $\mathrm{N}$ and full amount of other nutrients were incorporated as basal both for ginger and turmeric. Rest $\mathrm{N}$ for ginger was top dressed at $42 \mathrm{DAS}$ and for turmeric at 80 DAS. Plots were kept weed free for whole growing period. Irrigation and other intercultural operation were done as and when required. Data on yield and yield attributes were taken and analyzed statistically. Equivalent yield, gross return, gross margin and $\mathrm{BCR}$ were calculated. Pointed gourd equivalent yield (PEY) was calculated as follows: 
Efficiency of Intercropping Vegetables and Spices Relayed with Pointed Gourd

$\mathrm{PEY}=$ Yield of intercrop pointed gourd $+\frac{\mathrm{Yi} \times \mathrm{Pi}}{\text { Price of pointed gourd }}$

$\mathrm{Yi}=$ yield of intercrops (vegetables/spices)

$\mathrm{Pi}=$ Price of intercrop (vegetables/spices)

Land equivalent ratio (LER) values were determined from the yield data of the crops according to Mian (2008).

$\mathrm{LER}=\mathrm{RY}_{\mathrm{p}}+\mathrm{RY}_{\mathrm{i}}=\frac{\mathrm{P}_{\mathrm{IY}}}{\mathrm{P}_{\mathrm{SY}}}+\frac{\mathrm{P}_{\mathrm{EYCC}}}{\mathrm{P}_{\mathrm{SY}}}$

Where,

$\mathrm{RY}_{\mathrm{p}}=$ Relative yield of pointed gourd (main crop)

$\mathrm{RY}_{\mathrm{i}}=$ Relative yield of intercrops (vegetables and spices)

$\mathrm{P}_{\mathrm{YY}}=$ Intercrop yield of pointed gourd

$\mathrm{P}_{\mathrm{SY}}=$ Sole crop yield of pointed gourd

$\mathrm{P}_{\mathrm{EYCC}}=$ Pointed gourd equivalent yield of component crops \{ (component crop yield in intercrop price of component crop)/price of pointed gourd\}.

\section{Results and Discussion}

\section{Yield and yield contributing characters of pointed gourd}

There was no significant difference in yield and yield attributes of pointed gourd due to intercropping of vegetables/spices (Table 1). The number of fruits plant ${ }^{-1}$ was statistically similar in different treatment combinations and it ranged from 79.70 to 91.00 . The maximum number of fruits plant ${ }^{-1}$ was obtained in sole pointed gourd (91.00) while number of fruits plant $^{-1}$ was recorded in two times spinach + two rows turmeric in between pointed gourd lines . The maximum fruit weight plant ${ }^{-1}$ was recorded in sole pointed gourd but it did not vary significantly due to intercropping. Fruit weight ranged from 3.37 to $4.11 \mathrm{~kg} \mathrm{plant}^{-1}$ in different treatment combinations. The maximum fruit yield $\left(46.33 \mathrm{t} \mathrm{ha}^{-1}\right)$ was obtained from sole pointed gourd which was at par with other intercropped combinations. Among the intercropped combinations, the highest pointed gourd yield $\left(45.08 \mathrm{t} \mathrm{ha}^{-1}\right)$ was recorded in two times lalshak + two rows turmeric in between pointed gourd lines intercropped combination. The lowest pointed gourd yield $\left(43.18 \mathrm{t} \mathrm{ha}^{-1}\right)$ was found in two times spinach + two rows turmeric in between pointed gourd lines combination.

Table 1. Yield contributing characters and yield of pointed gourd (pooled of 2007-08 and 2008-09)

\begin{tabular}{c|c|c|c}
\hline Treatments & $\begin{array}{c}\text { Fruits plant } \\
\text { (no.) }\end{array}$ & $\begin{array}{c}\text { Fruit weight plant } \\
(\mathrm{kg})\end{array}$ & $\begin{array}{c}\text { Fruit yield } \\
\left(\mathrm{t} \mathrm{ha}^{-1}\right)\end{array}$ \\
\hline $\mathrm{T}_{1}$ & 91.00 & 4.11 & 46.33 \\
$\mathrm{~T}_{2}$ & 83.51 & 3.74 & 45.08 \\
$\mathrm{~T}_{3}$ & 79.70 & 3.45 & 43.18 \\
$\mathrm{~T}_{4}$ & 84.70 & 3.87 & 43.31 \\
$\mathrm{~T}_{5}$ & 83.45 & 3.66 & 44.84 \\
$\mathrm{~T}_{6}$ & 79.76 & 3.47 & 44.67 \\
$\mathrm{~T}_{7}$ & 83.83 & 3.37 & 44.10 \\
\hline LSD $_{(0.05)}$ & $\mathrm{NS}$ & $\mathrm{NS}$ & $\mathrm{NS}$ \\
$\mathrm{CV}(\%)$ & 8.93 & 11.97 & 5.19 \\
\hline
\end{tabular}

$\mathrm{CV}=$ Coefficient variance, $\mathrm{LSD}=$ Least significant difference, $\mathrm{NS}=$ Not Significant 
Islam et al.

\section{Component crop yield}

On an average of two years result showed that the yield of lalshak (red amaranth), spinach, bushbean, turmeric and ginger under intercrops were ranged 11.76-12.10, 11.59-11.74, 9.38-10.05, 21.09-22.85 and 16.81-18.07 $\mathrm{t} \mathrm{ha}^{-1}$, respectively (Table 2). It was revealed that, among the vegetables, lalshak (red amatanth) showed higher yield (11.76-12.10 $\mathrm{t} \mathrm{ha}^{-1}$ ) in intercropping system followed by spinach (11.59-11.74 tha-1). Similarly, between the spices crops turmeric showed higher yield (21.09-22.85 $\left.\mathrm{t} \mathrm{ha}^{-1}\right)$ than ginger $\left(16.81-18.07 \mathrm{t} \mathrm{ha}^{-1}\right)$ in intercropping. Joyachandran et al. (1991) reported from India that higher fresh ginger and turmeric yield was obtained in intercropping situation than sole crop due to shady condition than those in open sunlight. The result was in agreement with the findings of Bendall and Duly (1988). Similar findings were also observed in the experiment where ginger / turmeric yield was found higher in intercropping combination just because ginger / turmeric was grown under partial supports (Paulose, 1973 and Ahmed et al. 1998).

Table 2. Yield of component crops with pointed gourd under intercropping vegetables and spices relayed with pointed gourd inter cropping system (pooled of 2007-08 and 2008-09)

\begin{tabular}{c|c|c|c|c|c}
\hline Treatments & $\begin{array}{c}\text { Lalshak } \\
\text { (two times) } \\
\left(\mathrm{t} \mathrm{ha}^{-1}\right)\end{array}$ & $\begin{array}{c}\text { Spinach } \\
\text { (two times) } \\
\left(\mathrm{t} \mathrm{ha}^{-1}\right)\end{array}$ & $\begin{array}{c}\text { Bushbean } \\
\left(\mathrm{t} \mathrm{ha}^{-1}\right)\end{array}$ & $\begin{array}{c}\text { Turmeric } \\
\left(\mathrm{t} \mathrm{ha}^{-1}\right)\end{array}$ & $\begin{array}{c}\text { Ginger } \\
\left(\mathrm{t} \mathrm{ha}^{-1}\right)\end{array}$ \\
\hline $\mathrm{T}_{1}$ & - & - & - & - & - \\
$\mathrm{T}_{2}$ & 12.10 & - & - & 21.13 & - \\
$\mathrm{T}_{3}$ & - & 11.59 & - & 21.09 & - \\
$\mathrm{T}_{4}$ & - & - & 10.05 & 22.85 & - \\
$\mathrm{T}_{5}$ & 11.76 & - & - & - & 16.81 \\
$\mathrm{~T}_{6}$ & - & 11.74 & - & - & 18.07 \\
$\mathrm{~T}_{7}$ & - & - & 9.38 & - & 17.47 \\
\hline
\end{tabular}

$\mathrm{T}_{1}=$ Sole pointed gourd, $\mathrm{T}_{2}=$ Two times lalshak + two rows turmeric in between pointed gourd lines, $T_{3}=$ Two times spinach + two rows turmeric in between pointed gourd lines, $T_{4}=$ One time bushbean + two rows turmeric in between pointed gourd lines, $T_{5}=$ Two times lalshak + two rows ginger in between pointed gourd lines, $T_{6}=$ Two times spinach + two rows ginger in between pointed gourd lines, $T_{7}=$ One time bushbean + two rows ginger in between pointed gourd lines

\section{Pointed gourd equivalent yield (PEY)}

The produced all the component crops were converted into pointed gourd equivalent yield on the basis of existing market price for determine comparative efficiency of different treatment combinations. Pointed gourd equivalent yield was referred to total productivity. Pointed gourd equivalent yields were higher in all the intercrops (71.22-105.92 $\left.\mathrm{t} \mathrm{ha}^{-1}\right)$ than the sole crop of pointed gourd (46.33 $\mathrm{t} \mathrm{ha}^{-1}$ ) (Table 3). The maximum pointed gourd equivalent yield (105.92 $\mathrm{t}$ $\mathrm{ha}^{-1}$ ) was recorded in two times spinach + two rows ginger in between pointed gourd lines combination which was followed by one time bushbean + two rows ginger in between pointed gourd lines combination (105.89 $\left.\mathrm{t} \mathrm{ha}^{-1}\right)$.The total productivity increase of 53.72-128.62 percent over sole pointed gourd where two times spinach + two rows ginger in between the pointed gourd lines combination increased the highest total productivity (128.62\%). 
Efficiency of Intercropping Vegetables and Spices Relayed with Pointed Gourd

\section{Land equivalent ratio (LER)}

The land equivalent ratio (LER) in all the intercropping system was efficient having LER values more than 1.0 (Table 3). LER of different crop combination ranged from 1.54 to 2.29 indicating 54-129\% yield advantage by intercropping. The maximum LER value (2.29) was found from two times spinach + two rows ginger and one time bushbean + two rows ginger in between two rows of pointed gourd combination.

Table 3. Pointed gourd equivalent yield (PEY) and land equivalent ratio (LER) under intercropping vegetables and spices relayed with pointed gourd cropping system (pooled of 2007-08 and 2008-09)

\begin{tabular}{c|c|c|c}
\hline Treatments & $\begin{array}{c}\text { PEY } \\
\left(\mathrm{t} \mathrm{ha}^{-1}\right)\end{array}$ & LER & $\begin{array}{c}\text { \% increase of total } \\
\text { productivity }\end{array}$ \\
\hline $\mathrm{T}_{1}$ & 46.33 & 1.00 & - \\
$\mathrm{T}_{2}$ & 73.47 & 1.59 & 58.57 \\
$\mathrm{~T}_{3}$ & 71.22 & 1.54 & 53.72 \\
$\mathrm{~T}_{4}$ & 76.21 & 1.64 & 64.49 \\
$\mathrm{~T}_{5}$ & 102.33 & 2.21 & 120.87 \\
$\mathrm{~T} 6$ & 105.92 & 2.29 & 128.62 \\
$\mathrm{~T} 7$ & 105.89 & 2.29 & 128.55 \\
\hline
\end{tabular}

\section{Economics}

Intercrop combination had showed higher economic return than sole crop (Table 4). The highest gross return (Tk. $2118480 \mathrm{ha}^{-1}$ ) was found from two times spinach + two rows ginger in between pointed gourd lines combination. One time bushbean + two rows ginger in between pointed gourd lines combinations gave the highest gross margin (Tk. 1623333 ha $^{-1}$ ) and BCR (4.19) followed by two times spinach + two rows ginger in between pointed gourd lines combination. Among the intercrops, the lowest gross return (Tk.1424480 ha-1), gross margin (Tk. 994990 ha $^{-1}$ ) and BCR (3.32) were obtained from two times spinach + two rows turmeric in between pointed gourd lines combination. Sole crop of pointed gourd gave the lowest gross return (Tk. $926600 \mathrm{ha}^{-1}$ ), gross margin (Tk. $597454 \mathrm{ha}^{-1}$ ) and BCR (2.82). The results indicated that intercropping was highly productive and profitable as compared to sole stand.

Table 4. Economics of intercropping vegetables and spices relayed with pointed gourd cropping system (pooled of 2007-08 and 2008-09)

\begin{tabular}{|c|c|c|c|c|}
\hline Treatments & $\begin{array}{c}\text { Gross return } \\
\left(\text { Tk.ha }^{-1}\right)\end{array}$ & $\begin{array}{l}\text { Total cost } \\
\left(\text { Tk.ha }^{-1}\right)\end{array}$ & $\begin{array}{c}\text { Gross margin } \\
\left(\text { Tk.ha }{ }^{-1}\right)\end{array}$ & BCR \\
\hline $\mathrm{T}_{1}$ & 926600 & 329146 & 597454 & 2.82 \\
\hline $\mathrm{T}_{2}$ & 1469400 & 418878 & 1050522 & 3.51 \\
\hline $\mathrm{T}_{3}$ & 1424480 & 429490 & 994990 & 3.32 \\
\hline $\mathrm{T}_{4}$ & 1524200 & 398846 & 1125354 & 3.70 \\
\hline $\mathrm{T}_{5}$ & 2046520 & 514499 & 1532021 & 3.98 \\
\hline T6 & 2118480 & 525111 & 1593369 & 4.03 \\
\hline T7 & 2117800 & 494467 & 1623333 & 4.19 \\
\hline
\end{tabular}

Market price: Pointed gourd: Tk.20.00 kg-1, Lalshak: Tk.12.00 kg-1, Spinach: Tk.12.00 kg-1, Bushbean: Tk.15.00 kg-1, Turmeric: Tk.20.00 kg-1, Ginger: Tk.60.00 kg-1 
Islam et al.

\section{Conclusion}

The result revealed that the maximum monetary returns in respect of gross margin (Tk. $1623333 \mathrm{ha}^{-1}$ ) and BCR (4.19) could be obtained with one time bushbean + two rows ginger in between pointed gourd lines combinations. Therefore, farmers should be interested to grow pointed gourd at wider spacing $(1 \mathrm{~m} \times 1 \mathrm{~m})$ intercropped with vegetables and relayed of spices instead of monoculture of pointed gourd.

\section{References}

Ahmed, N. U., M. M. Rahman, M. M. Hoque and A. K. M. Amzad Hossain. 1998. Effect of seed size and spacing on the yield of ginger. Bangladesh Hort. 16(2): 50-52.

Bangladesh Bureau of Statistics (BBS). 2011. Statistical Year Book of Bangladesh. Statistics Division, Ministry of Planning, Government of the Peoples Republic of Bangladesh, Dhaka.

Bendall, R. L. and R. A. Duly. 1988. Ginger growing in the Nambour area, queens land, Quarterly Rev. Agril. Econ. 19: 86-96.

Haque, M. M. and S. M. M. Hossain. 1985. Spice and root crops in the context of homestead garden in Bangladesh. Workshop proceedings, present status and future prospects of research on root and spice crops. BARC, p 51.

Islam, M. R., M. A. K. Main, N. Ara and M. F. Hossain. 2013. Intercropping lentil and turmeric relayed with pointed gourd. Bangladesh J. Agric. Environ. 9(1): 33-37.

Joyachandran, B. K., M. M. Bai, M. A. Salam, M. K. Mannan and K. P. Mathew. 1991. Performance of ginger under shade and open condition. Indian Coca, Arecanut and Spices J. (2): 40-42.

Mian, M. A. K. 2008. Performance of maize oriented cropping patterns under different nutrient management. Ph. D. Dissertation. Dept. Agron. Bangladesh Agril. Univ., Mymensingh. pp. 31-137.

Paulose, T. T. 1973. Ginger cultivation in India, Proceedings of the conference on spice 10-14 April, 1972. Tropical Products Institute, London. 